\title{
Emotional and Cognitive Influence in Extraordinary Situations - Psychological Study of Responses with Content Analysis Methods
}

\author{
Marianna SCHILD, ${ }^{1}$ Lívia SZIJÁRTÓ²
}

\begin{abstract}
The experience of extraordinary situation influences the whole personality. Nowadays the dominant crises - events such as war, natural disasters, economic crises and terrorism - affect an individual's emotional, cognitive and behavioural responses. The emerging security challenges require adequate prevention strategies and crisis intervention, which involves the analysis of the psychological processes with modern methods. This paper shows the effectiveness of the psychological methods in the management of such situations. The article is divided into several parts; the first part is a general definition of special situations, the second is the presentation of the emotional and physiological consequences, while the third deals with the description of the cognitive aspects. The final part of the study attends to the psychological content analysis in emergencies as a possible research area.
\end{abstract}

Keywords: extraordinary situations, crisis, psychological methods, emotional, physiological and cognitive aspects, psychological content analysis

\section{Introduction}

The new types of security challenges of the $21^{\text {st }}$ century require the modern definition of extraordinary situations and their consequences. The termination of the Cold War reduced the possibility of interstate conflicts; new conflicts such as the regional and intra-state tensions emerged, these have negative impact on international stability. Furthermore, the transnational threats - such as terrorism, cybercrime, proliferation of mass destruction weapons, the depletion of natural resources and the natural disasters - have created new challenges for the defence sector.

The adequate recognition and management of the above-mentioned extraordinary situations can prevent unfavourable consequences of such conflicts. The present study focuses on the extraordinary situation as a psychological phenomenon and explores its psychological impact on individuals. Dangerous situations cause emotional, behavioural and cognitive reactions and the intensity of these responses depends on the individual's psychological condition as well as on the current situation. Analysing the extraordinary situation is an important step towards the understanding of the responses. In everyday language, extraordinary situations are phrased as extreme situation, urgency, crises. In this paper, we analyse the types and characteristics of these situations.

1 National University of Public Service, Doctoral Schools of Military Sciences; e-mail: schild.marianna@gmail. com

2 National University of Public Service, Doctoral Schools of Military Sciences; e-mail: szijartolivia@gmail.com 


\section{The Possible Definitions of Extraordinary Situations}

In the Conflict Theory of Michael S. Lund crisis is described as a space, where the beginning is represented by peace, i.e. conflict-free state, and the end of the continuum is war. When, for any reason, peace is disturbed, unstable peace, crisis or armed conflict emerge. In Lund's theory, these situations are extraordinary situations. Furthermore, the operations to resolve peace, as preventive diplomacy, crisis management, peace enforcement, peacekeeping and peace establishment missions are enclosed in this definition as well. [1] [2] Boutros Boutros Ghali's peace operations ${ }^{3}$ (conflict prevention, peacekeeping, humanitarian operations, etc.) are also extraordinary situations. Attila Murinkó concludes in his thesis ${ }^{4}$ [3] that the term "extraordinary situation” comprises any unusual events including military enforcement and aggression.

However, the term "extraordinary situation” can be interpreted not only in military terminology. Crisis can emerge from any unexpected situation of law enforcement, which effects the mental and physical condition of individuals. [4] Unexpected situations include the operations on the battlefront, the political disturbances, industrial and natural disasters and any unusual circumstances. Natural disasters and destructive human activity often result in extraordinary situations. Although the disasters caused by extreme weather conditions are not associated with human activity (earthquake, tsunami, flood), some experts classify disasters originated from global warming and the depletion of natural resources as destructive human behaviour. The disasters caused by destructive human behaviour are characterized as events initiating from human failure. [5]

The next sections present the above-defined extraordinary situations in details from the law enforcement and national security point of view.

\section{Foreign Military Operations}

The military personnel of the Hungarian Defence Force often perform operational missions in foreign countries due to their obligations towards NATO (North Atlantic Treaty Organization) and the Constitution of Hungary. The primarily peacekeeping operations and missions are demanding both physically and emotionally; therefore, they are extremely challenging for the personnel of the armed forces. Despite the precise selection procedure and the preparation measures, unexpected difficulties may occur leading to various physical and mental pathologies causing severe damages to both the individual and the organization.

The social interactions in the unfamiliar environment, the language and the cultural differences can be overwhelming, thus leading to increased stress in the long term. The fact that the individual cannot influence his/her environment can stimulate a sense of inability, consequently, a loss of self-esteem. This phenomenon is the so-called "culture shock", which is caused by information overload, language or generation gap, homesickness, work addiction or boredom. The foreign environment can create anxiety or disorientation in the individuals. The lack of familiar reference points in social interactions may lead to tension between the soldiers and the local community. After only a few months, the stress and deprivation of

3 Boutros Boutros Ghali is an Egyptian politician, he was the Secretary-General of United Nations (UN) from January 1992 to December 1996.

4 Attila Murinkó wrote his thesis about the coaching of the special situations. 
family and friends is followed by difficulties to implement the operational tasks in a foreign country. [6]

In addition to the above-mentioned culture shock, the stress caused by the battlefield is a significant potential for crises, causing major problems in foreign military operations. Stressful situations belong to the everyday experiences on the battlefield. To survive these situations, and to cope with the circumstances, soldiers need to have extraordinary adaptive skills. The personnel of the armed forces may respond to this stress by increasing fear or acute stress reaction. In long-term military service, there are many mental, physiological and environmental stimulations, so-called combat stressors. Physical stressors include extreme temperatures, asphyxia, chemical and radiation danger. Physiological stressors include insomnia, dehydration, hunger, poor health conditions, illness or injury. In addition, mental stressors cover for example too little/too much information, overload of sensory organs, organizational and decision-making problems; furthermore, fear or threat of e.g. death, injury, loss, exasperation, anger or irritation can act as stressors as well. [7]

\section{Industrial and Natural Disasters}

In addition to crises resulting from military action, the $21^{\text {th }}$ century acknowledges further security risks in the form of industrial and natural disasters. Despite the high technology development, such events are not precisely predictable; nevertheless, having serious consequences. The disaster, by definition, is an event that endangers the life or health of many people, causes material, environmental and economic losses, damages the basic care and services in such an extent that the intervention of authorities, institutions and organizations is necessary to repair the previous state. [8]

The individual often behaves unexpectedly in emergencies because he/she instinctively performs actions to protect him/herself from physical harm. As long as the unusual behaviour serves the resolution of the situation, it is a valid adaptive response. However, if the irrationally narrowed-minded and egocentric behaviour dominates, then permanent behavioural disorder prevails. [9: 17-19] At disaster-events, extreme behaviours appear instantly, which require constant monitoring and treatment, otherwise the individual might become dangerous towards himself and others. The most important symptoms of such behaviour are extreme anxiety, stupor, physical reactions (e.g. hyperventilation, hypertension, vomiting), cognitive deficits (confusion, ambivalence, depression, suicidal thoughts) and affective responses such as fear or frustration. [10]

\section{Terrorism as extraordinary situation}

In the $21^{\text {st }}$ century, terrorism represents the biggest crisis in addition to military operations and natural disasters. After terrorism became a worldwide threat, it turned into the main security challenge in the world. The terrorist act, by definition, is such a purposeful or accidental murder, which causes permanent injury, and which targets mainly civilians to achieve political, religious or ideological goals. The terrorists intend to influence the government or the state authority using assassination, kidnapping and bomb attacks. [11] Such actions are determined to provoke and to communicate symbolic messages generating extreme fear in the enemies on the way. 
The motivation of these attacks is usually political or religious fanaticism, which is often associated with extreme aggression. The terrorist evaluates every consideration, action and event from the aspect of the main ideology (e.g. the terrorist organization called the Islamic State and its expansion in the Middle East) and he shows intolerance for contrary opinions; furthermore, he aims to destroy anything, which is not in line with his own fanatical beliefs. The fanatical extremist groups exploit those individuals whose personality can be transformed into the above-mentioned fanatic identity. In the psychological term these individuals have fitting character for sadism, masochism, and absolutism they have often narcissistic personality disorder, identity crisis, loss of self-integration and they are attributed to lack of autonomy and social norms and deficiency of aims and motivations. The terrorist-candidate experiences the role of his idol (often his mentor) by imitating the behaviour of the admired person. Often the candidate identifies him/herself with the idol thereby believing he can become an identical member of the group. [11: 24]

In addition to the above detailed situations, other political, economic and regional conflicts can lead to extraordinary situations, which can cause similar behavioural disorders. The above sections clearly state that extraordinary situations result in crisis conditions, which lead to mental, emotional, cognitive and behavioural consequences. Moreover, the direct effect of the crisis can be anxiety, insecurity, fear, narrowing of the capability of decision-making, irrational thinking and incorrect adaptation of resolving strategies. [12] For the better understanding of the psychological responses, it is necessary to present the psychological approach of crisis theory.

\section{The Term "Crisis"}

Crisis is a Greek word, meaning decision or turning point, in everyday usage it is used in all kinds of crises, critical status or emergency. [12] A crisis can originate from psychological, biological and economic causes. The crisis is unexpected, it has an emotional tone, and it causes a feeling of fear, helplessness and decreased consciousness. Crisis leads to an imbalance resulting in partial or complete personality dysfunction. [13]

Two types of crisis are distinguished: the developmental or normative (internal) crisis, which covers the individual development crises such as puberty or menopause, the other is the accidental (external) crisis, which is initiated by an incidental situation that affects the individual. Such situations can be natural disasters (earthquake, flood, storm, hurricane, tsunami, etc.), human-caused disasters (war, fire, bombings, mass catastrophes, terrorist attacks) and other accidents. The above-described extraordinary situations are all such incidental situations, additionally more ordinary situations are robbery, violence crime, financial bankruptcy, loss of job or a threat of serious illness. [14]

\section{Behavioural and Physiological Responses to a Crisis}

In crisis, individuals produce specific physiological reactions, which induce changes in the behaviour. In an emergency, the individual often experiences fear, which develops stress-responses. Stress originally meant only physical overload, however, its modern terminology covers generally a situation whereby someone feels overwhelmed physically or psychologically. [15: 467] The person evaluates events as stressful whenever he or she feels that the cir- 
cumstances endanger his/her physical or mental well-being. In a stress situation, the human body is preparing to eliminate the stressors. The sympathetic nervous system generates stress responses such as increased heart rate, faster breathing, the mouth dries out, the Adrenocorticotropic hormone (ACTH) is produced, which increases the production and release of cortisol into the blood, causing increased blood pressure, blood sugar level and suppression of the immune system. The liver produces more glucose, providing more energy to the body. This so-called fight-or-flight response is an acute stress response, which activates the body to have more energy for fighting or running. This state can be dangerous to the individual or to others. [16: 541]

\section{The Stress-Related Emotional Responses}

In the stressful situations, besides the emotional and behavioural responses, the physiological reactions are important. Most dominant are anxiety and fear: anxiety and fear are not interchangeable processes, as anxiety is an emotional response to the thread, while fear is a cognitive process when the stimulus (i.e. thread) is evaluated intellectually. Anxiety causes faster heartbeat, tremors, nausea, and dizziness. Fear activates when an individual is exposed to a physically or psychologically threatening situation. [17: 6-8]

Other psychological reactions are anger and aggression, emotions which are usually related to frustrations such as unachieved goals, realization of material damages or a loss of an important person. The response to a given frustration is different from person to person, nevertheless, if the anger prevails for a long time, it becomes a stressor itself, leading to physical symptoms. [15: 231] Conceptual definition of the aggression originating from frustration is such an "offensive behaviour, which is triggered by hostile, often irritating experiences. The offensive behaviour can be self-directed or intended to harm others, can be conscious or unconscious, can be direct or indirect, moreover, it can convert into other forms (e.g. anxiety and physical symptoms of repressed aggression).” [18: 24] In contrast to the generally negative meaning associated with aggression, a positive or actually constructive aggression exists, because a certain level of aggression is necessary for the self-sustainment, for the self-defence and for the protection of the family as well.

In addition, depression can occur in stressful situations, which causes a feeling of sadness, anxiety, emptiness or helplessness. Depression, also known as melancholy is characterized by excessive reactivity or inactivity, and if it is a reaction to a life event such as grief, it can have higher intensity and longer duration than normal. Depression is a mental disorder, which negatively affects the person's whole life, his/her everyday performance, the general well-being, the physical and mental functions, and his/her human relationships. [19: 27] Symptoms can be on cognitive, affective, conative and a physical level. Characteristics of depression are the extreme unhappiness, the loss of the interest, inability to experience pleasure; these are associated with typical cognitive and physical symptoms (e.g. slower movements). [19: 27] Anxiety, low self-esteem, negative expectations, emotional paralysis, lethargy, self-hatred are all possible symptoms of depression. 


\section{The Cognitive Aspects of Extraordinary Situations}

According to Bolgár and Szekeres, the characteristics of the behaviour in an emergency appears in four levels: physiological, cognitive, emotional and behavioural dimensions. [12: 10] In the previous chapters, the physiological and emotional aspects of the extraordinary situations have been presented; however, the cognitive processes cannot be ignored in the extraordinary crisis and in the related decision-making processes. Cognitive processes include the difficulty of decision-making, confusion, disorientation, poor concentration, memory deficits, inability of solving complex problems and occasionally flashbacks. [12: 10] The individual cognitive structure can change in a stressful situation, which entails impaired consciousness and hallucinations.

The revolution of cognitive psychology ${ }^{5}$ reflects on the particular situation, its individual interpretations and its decisive cognitive processes. Everly et al. [20] studied the psychological effects of Hurricane Katrina, when they concluded that the cognitive elaboration of an event is the best predictor of the evolved stress. The study highlights the effectiveness of cognitive behavioural therapy in coping with the specific situation, the method of which is based on the conception that the primary determinant of human behaviour is the learning/ cognitive process. The theory states that in the background of the dysfunctional behaviour there is always problematic thinking. Accordingly, the changing of maladaptive cognitive schemas can help the individual to cope with crises.

\section{Decision-Making in an Extraordinary Situation}

The subjective interpretation of reality is particularly important because it determines the decisional coercion of the extraordinary situation. According to Stern [21] we talk about decisional crisis when the situation threats essential interests, requires urgent action and it is associated with a high degree of uncertainty. Based on Mezey’s decision-making model [22] the individual perception is the first step of a decision that involves the situational awareness. The normative interpretation of the given situation results in rational decision, although due to the special conditions the rationality may be limited as well. ${ }^{6}$ The situation awareness in extraordinary circumstances and the following decision-making process can trigger distinct behavioural schemas as cooperative or provocative.

The military conflict as an extraordinary situation, similarly to the need of decision-making requires specific cognitive abilities. According to a study about US military crises done in 2010, [23] the decision-making of the military leaders requires creative thinking, a high level of problem-solving skills and adequate comprehension in a military action. In the article, the approach of the military personnel is summarized, which describes the cognitive heuristics and bias used in a stressful decision-making situation. Due to the uncontrollable amount of information and a large number of sensory inputs, an individual is unable to interpret them,

5 In the seventies of the last century the cognitive perspective see the individual as a recognizer agent against the long dominant behaviourist approach, the new perspective's central concept was the subjectivity and the representation. According to the cognitive approach the individual constructs the reality with strategies based on his environment, previous experience and cognitive processes, with this he exclude the objectivity.

6 The alternatives of the acts are defined by the decision criteria, the weighting of the aims and the multiphasic analysing in the normative decision-making model. 
because the soldier uses simplifications and pre-programmed schema of thinking. Williams argues that facing new circumstances, the individual will compare them to similar situations residing in the memory, prior to adopting the behavioural plan. This is connected to retrievability bias, which means that the subjective probability of future events is related to the personal experience. People after experiencing a traumatic event expect that it will happen again.

Summarizing, we can see that decision-making involves both the general cognitive abilities and the subjective heuristics. Bolgár and Szekeres [12: 26-27] used the theory of Tversky and Kahneman's 1974, ${ }^{7}$ to classify the thinking processes into three categories. The availability heuristic is a decision-making method, when the subjective probability of the particular events is based on the ease of imagining or recalling a similar event from memory. The adjustment and anchoring is heuristic, when people make decisions by using a reference point, to which the result will be correlated, regardless how relevant this reference point in the current question is. The representativeness heuristic arises if a situation is categorized to a certain type, i.e. when the situation is compared to a prototype of a certain category.

\section{Cognitive Deficits in the Crises}

Our study suggests that the individual applies cognitive bias in an emergency based on previous experiences and this bias can significantly affect the decision-making. In the last decades, the psychological research emphasises the post-traumatic stress (referred to as post-traumatic stress syndrome (PTSD) ${ }^{8}$ following an extraordinary situation. PTSD influences negatively on the mental health of the individual, especially on the operation of cognitive functions. To better understand the information processing errors; it is necessary to clarify the concept of PTSD. This disorder has the following main symptoms: [20]

- intrusive memories,

- recurrent recollections of the traumatic event,

- nightmares,

- intrusive images,

- depressive symptoms,

- avoidance of trauma-related people,

- places and thoughts,

- symptoms of increased arousal, such as irritability, sleep disturbance, outbursts of anger. The cognitive behavioural therapy of post-traumatic stress approaches the information processing deficits related to the traumatic event.

The false interpretive procedures, which follow the stress, involve maladaptive coping strategies and dysfunctional problem-solving skills. One example is the terror attack in Oklahoma City in $1995,{ }^{9}$ and its first erroneous interpretation: after the incident, the police investigators suspected terrorists from the Middle East, because previous experiences, the threat from al-Qaeda and the interpretation of the assassination suggested that Islam terrorists were responsible for the attack. [21]

7 Amos Tversky and Daniel Kahneman (1970) developed the theory of the operation of human errors and cognitive biases. Their research significantly contributed to the development of cognitive psychology.

8 Post-traumatic stress syndrome (PTSD) first appeared in 1980 in Diagnostic and Statistical Manual of Mental Disorders (DSM, published by the American Psychiatric Association).

9 Timothy McVeigh, a former US soldier detonated two bombs in April 1995 in Oklahoma City. 168 people were killed in the attack, the bomber was executed in 2001. 
The heuristics and the preconceptions, used in information processing, play a significant role in developing false interpretations of the situation. The monitoring of the complex physical and social environment is inherently limited because of the infinite number of inputs; additionally, the stress and the motivation of the problem solving can also negatively affect the actions taken for interpretation. A person suffering from PTSD is likely unable to process the crisis in real-time, he/she may attach higher global importance to the negative effects. The individual overestimates the threats associated with the traumatic event, his/her fears about the future are irrational. Because of the intrusive memories, the person feels he/she is losing control, and because of the dominance of negative emotions, he/she starts to use maladaptive coping strategies. Hence, the mental illness of the individual causes a damaged autobiographical memory, which is not able to process and integrate the trauma related memories. [24]

According to Artman and Garbis [25] the failure or dysfunction of the mental capacity reduces the use of an adaptive coping strategy in extraordinary situations, because it negatively affects the processing of information. The study points out that cognition is not a static construct, but it dynamically changes depending on external factors. The awareness of situation can be understood at the individual level; therefore, the cognitive process and situation awareness of a group, organization or country is based on the capability of the individuals, and the common action is determined by the interaction between these individuals.

\section{Content analysis methods of extraordinary situations}

In addition to the psychological aspects, the cognitive process also play an important role in managing extraordinary situations, in decision-making and in behavioural responses. One way of testing the reactions to crises is the psychological content analysis. The analysis of the communication and the narratives in traumatic events contributes to the understanding of the emotional, behavioural and cogitative responses following the extraordinary situations.

\section{The definition of content analysis}

Content analysis is increasingly used in social sciences, and it is an analysis method of publications and documents for specific purposes; primarily of the oral and written materials. [26] The method consists of two parts. In the encoding phase, the words, phrases and symbols are detected and categorized. In the next, interpretation phase, these variables are analysed and the hidden associations are identified. Smith suggests [27] that the content analysis can identify the underlying meaning of the text, till Berg suggests [28] that the method allows an objective examination of a particular text. The narrative psychological content analysis is the most used tool in Hungary, it is a method developed by János László and his colleagues. ${ }^{10}$ The method searches for grammatical categories and functions, and derives a psychological meaning from them. According to László, [29] a relationship exists between the narrative compositions and psychological processes, as the narrative construction of the word is egocentric, and it is derived from the personal experiences of the narrator.

10 The experts from the University of Pécs and from the Institute of Psychology of the Hungarian Academy of Sciences (MTA) created a Hungarian basis for narrative psychology where the nature of narratives and the human behaviour can be examined. 
Marianna SCHILD, Lívia SZIJÁRTÓ: Emotional and Cognitive Influence in Extraordinary Situations...

\section{Literature review on content analysis of extraordinary situations}

The interpretations, related to the extraordinary situations, often explain the prevailing causalities of an event, although, the alternative narratives, which help to process the crises, can assist the better understanding of the event. After a traumatic event, the public opinion also affects the judgment of those who are in decision-making power. Furthermore, content analysis is not only applicable in the field of interpretations and opinions, but also can be used in investigating the consequences of the crises. The method is mainly applied in the business sector, because the companies affected by the economic crisis strongly support crisis communication and crisis management. Crisis communication and management are used in a crisis situation by companies, communities and social organizations.

Much international research has examined crisis communication and management of economic companies: a study from 2013 [30] compares the industrial disaster of British Petroleum to the Japanese earthquake and the accident of the Fukushima nuclear power plant along the strategy of crisis communication. ${ }^{11}$ The author examined these communication strategies with content analysis, the examined texts were press releases and posts from Twitter and Facebook. The research addressed the strategy of the companies to inform the public, and the level of information sharing. In the strategies of crisis, communication it has the most important aim to minimize the damage. This study points out the importance of the Internet, hence it greatly affects communication approaches. Nowadays individuals get information about traumatic events through social networks; therefore, the companies and organizations are unable to control the range of available information and data related to the accidents. Information related to crisis or disasters receive more attention on the Internet, thereby the leaked information to the public is not controlled.

The content analysis research, examining extraordinary situations investigates mainly economic events and their communication strategies used by multinational companies. However, studies about riots, violent political protests or military conflicts are published as well. An article from 2012 [31] examines the crisis communication strategies of leaders after the demonstrations in Tunisia and Egypt in 2010-2011. The author states ${ }^{12}$ that the political speeches are special, because they contain less information and are often manipulative and persuasive. The author concludes that the main aims of the speeches were to preserve the reputation and to rebuild the authority of the leaders, to which different tools were used:

- The nonexistence strategies aim at ending the crisis using communication tools as denial, clarification, attack and intimidation. The leader attempts to diminish the relation between his actions and the crisis, and to trivialize the events.

11 The one of the world's biggest industrial disasters happened in April 2010, when the one of the oil rigs of the British Petroleum (BP) exploded and sank in the Gulf of Mexico. The enormous oil pollution has led to massive desolation of fishes and birds. A year later, the Japanese earthquake and tsunami materially damaged the Fukushima nuclear power plant operated by the Tokyo Electric Power Company (TEPCO). The damage produced equipment failures followed with three nuclear meltdowns, causing a large amount of radioactive pollutants into the air. Later it turned out, that neither BP nor the TEPCO did not have an adequate operation plan for a disaster.

12 The Tunisian protests began in December 2010, marked the beginning of the Arab Spring, and the riots spread across the North Africa and the Middle East region. The demonstrators were protesting against high unemployment, corruption and dictatorial measures. The events in Tunisia also spread to Egypt in early 2011, where the anti-Mubarak protests aimed at defeating the government. The events of the Arab Spring finally led to the demission of two North African presidents (Zine El Abidine Ben Ali, Hosni Mubarak). 
- The distance strategy differentiates from the nonexistence strategy in the leader's approach to the crisis. The speaker although admits the existence of the crisis, but he denies his responsibility in the events.

- The ingratiation strategy uses different communication tools. The leader admits the existence of the crisis, and highlights his strategy to resolve the situation. He specifies his positive steps towards the solution. The leader assures the public of his support and he praises the government's actions.

- The fourth strategy - mortification - is when the chief/leader emphasizes his responsibility in the events, shows remorse and promises to rectify the damages.

- The fifth - suffering - strategy is slightly different from the previous methods, aims at awakening the sympathy of the public and demonstrating/the leader as a victim, who was exploited by some external, malicious entity.

Alharbi examined the political speeches of Zine El Abidine Ben Ali, Tunisian head of state and Hosni Mubarak, Egyptian head of state, and concluded that the presidents used the above-mentioned forms of communication strategies, often combining them. The crisis communication strategies may help to protect or restore the leader's reputation; however, it does not guarantee the success of the political speech. According to the author, the content analysis of these speeches can contribute to our understanding of the political crisis in the Middle East.

Hart and his colleagues [32] studied in 2002, how the American people respond to the national events of great importance. ${ }^{13}$ The research made by content analysis methods showed that the crisis is followed by an increasing need for the national-wide introspection and the understanding of difficult events.

Summarizing, the extraordinary, unusual situations change the political and everyday communication; the normative forms of communication cannot be applied for such events.

\section{Conclusions}

The employment in the defence sector is different from civilian occupations. It is accompanied by increased risks on both physical and mental level. The military personnel have to be in good physical condition; furthermore, have to have exceptional psychological endurance. The members of the defence sector often have to take responsibility for other people's lives and material goods; they regularly experience time pressure and face decisions in difficult situations. Moreover, their duty is based on complex rules and instructions, and the work requires creativity and flexible thinking simultaneously.

Any emergency (military missions, disasters, terrorism, riots, etc.) will create a critical situation, and people will start to search for possible solutions. The victims, the civilians and professionals involved in the rescue are exposed to physical effects and psychological damages, long-term disorders. These may include post-traumatic stress disorder, somatization disorders, distress, anxiety or difficulties in social life. As it was discussed above, the respond to a crisis involves a complex psychological response; therefore, in extraordinary

13 The article studied the terrorist attacks in 2001 and Bill Clinton's constitutional impeachment. In the attack against the World Trade Center and the Pentagon were killed nearly 3,000 people, when Islamic terrorists hijacked four airplanes, while the cause of the Clinton's impeachment was his earlier sexual affair with a woman named Monica Lewinsky. 
situations, the fast and professional psychological intervention is important. Crisis management includes not only the intervention in the events and the work towards the resolution, but also the prevention of post-traumatic effects and the follow-up care of the psychological conditions of both the executive staff and the victims.

The empirical research of extraordinary situations in the defence sector is essential for adequate preventive actions. The experts cannot determine the adaptive preventive and intervention tasks without the up-to-date scientific results. The new types of security risks are associated with new challenges. The recent crisis, the international terrorism since the terrorist attacks of 2001, the political riots in the Middle East, the increasing frequency of natural disasters, the regional conflicts in Europe - see Ukrainian crisis - and their psychological impacts are important research areas of psychology.

The dysfunctional behaviour in the crisis is always based on emotional deficits and maladaptive cognitive schemas, while in a usual situation the individual can use the appropriate coping strategies. The main question is how these processes help the individual to adapt the particular emergency. According to the proposal of the present study, the psychological content analysis methods can identify the psychological aspects of adaptive coping strategies.

The individuals, who are involved in extraordinary situations, re-experience the trauma during the narrative of the events; thereby, they re-conceptualize the reality. The content analysis methods are appropriate to examine the participants' subjective perceptions and to determine the occurring psychological responses. Knowing the emotional and cognitive reactions allows the adequate treatment of a crisis. Taking the cognitive aspects as an example, well-functioning and efficient cognitive behavioural therapy does not exist without the recognition of the distortions and heuristics.

In the here discussed crises, the aspects of the responsible persons have to be considered next to the victims' psychological disorders. The crisis communication of the leaders involved in - mainly economic and political - crises significantly affects the outcome of an extraordinary situation and the possible consequences. In the communication of the responsibility and the information, it is important to repair the caused damages and to recover the political power in the new circumstances. The crisis management of the leaders is often investigated by content analysis techniques. These studies show that the analysed speeches and messages significantly affect the resolution of the crisis and the reactions of the responsible persons.

\section{References}

[1] LUND, M. S.: Conflict prevention: Theory in pursuit of policy and practice. In. BERCOVITCH, J., KREMENYUK, V., ZARTMAN, I. W. (Eds.): The SAGE Handbook of Conflict Resolution. 287-308. London: SAGE Publications Ltd., 2009.

[2] TÚRI V.: A pszichés terhelés hatása különleges helyzetekben, különös tekintettel a megküzdési stratégiák nemek szerinti változataira. Budapest: ZMNE, 2010. (PhD-értekezés)

[3] MURINKÓ A.: A különleges helyzetekre történő felkészítés szükségszerūsége és hazai megvalósításának lehetősége a Portyázó tanfolyam keretén belül. Budapest: ZMNE, 2007. (PhD-értekezés)

[4] BOLGÁR J.: Viselkedési kockázat veszélyhelyzetben (folyamatban lévő kutatás elméleti háttere alapján). Repüléstudományi Közlemények, 252 (2013), 32-38. 
[5] HORNYACSEK J.: A tömegkatasztrófák pszichés következményei és az ellenük való védekezés lehetőségei. Bolyai Szemle, XIX 4 (2010), 5-30.

[6] GORDA É. (2009).: A kulturális sokk jelenléte a haditudósító munkájában. Hadtudományi Szemle, 3 (2009), 52-60.

[7] PAVLINA Z., KOMÁR Z.: Katonapszichológia II. Budapest: HM Zrínyi Kommunikációs és Szolgáltató Kht., 2007.

[8] HORNYACSEK J.: A tömegkatasztrófák pszichés hatása a beavatkozó állományra, az alapvető korai és késői pszichés jelenségek, valamint a negatív következmények elkerülésének lehetséges módjai. Múszaki Katonai Közlöny, 221 (2012), 143-189.

[9] ZELLEI G.: Katasztrófapszichológia. Budapest: CEDIT Kft., 2011.

[10] KOVÁCS G.: A katasztrófapszichológia alapjai. Honvédorvos, 61 3-4 (2009), 171-181.

[11] KOVÁTS D.: A fanatizmus és a terrorizmus pszichológiai szempontú elemzése. Rendvédelmi füzetek, 12 (2002), 3-24.

[12] BOLGÁR J., SZEKERES GY.: Katasztrófa és kríziskommunikáció lélektani alapjai. Budapest: ZMNE, 2009. (Elektronikus jegyzet)

[13] SCHILD M.: A katonai létből adódó krízishelyzetek pszichológiai hátterei. Műszaki Katonai Közlöny, 241 (2014), 259-274.

[14] HAJDUSKA M.: Krízislélektan. Budapest: ELTE Eötvös Kiadó, 2008.

[15] BENESCH H.: SH atlasz - Pszichológia. Budapest: Springer Hungarica Kiadó, 1994.

[16] ATKINSON, R. C., HILGARD, E.: Pszichológia. Budapest: Osiris Kiadó, 2005.

[17] BECK, A., EMERY, G.: A szorongásos zavarok és fóbiák kognitív szemlélete. Budapest: Animula Kft., 1999.

[18] HÁRDI I.: Az agresszió világa. Budapest: Medicina Könyvkiadó, 2000.

[19] SZÁDÓCZKY E., RIHMER Z. (szerk.): Hangulatzavarok. Budapest: Medicina Könyvkiadó, 2001.

[20] EVERLY, G., PERRIN, P., EVERLY, G.: Psychological issues in escape, rescue and survival in the wake of disaster. Pittsburgh: National Institute of Occupational Safety and Health, Research Laboratory, 2008.

[21] STERN, E. K.: Crisis decision-making: a cognitive institutional approach. Stockholm: University of Stockholm, Department of Political Science, 1999.

[22] MEZEY GY.: Kockázat és döntés. Budapest: Aula Kiadó, 2010.

[23] WILLIAMS, B. S.: Heuristics and bias in military decision making. Military Review, 9-10 (2010), 40-52.

[24] EHLERS, A., CLARK, D. M.: A cognitive model of post-traumatic stress disorder. Behaviour Research and Therapy, 38 (2000), 319-345. DOI: https://doi.org/10.1016/ S0005-7967(99)00123-0

[25] ARTMAN, H., GARBIS, C.: Situation awareness as distributed cognition. In. GREEN, T., BANNON, L., WARREN, C., BUCKLEY, J.: Cognition and cooperation. Proceedings of Ninth Conference of Cognitive Ergonomics. 1-6. Limerick: ECCE’98, 1988.

[26] ANTAL L.: A tartalomelemzés alapjai (Gyorsuló idő). Budapest: Magvető Kiadó, 1976.

[27] SMITH, C. P.: Content analysis and narrative analysis. In. REIS, H. T., JUDD, C. M.: Handbook of research methods in social and personality psychology. 313-335. New York: Cambridge University Press, 2000.

[28] BERG, B.: Qualitative research methods for the social sciences. Fourth edition. Massachusetts: Allyn \& Bacon, A Pearsons Education Company, 2001.

[29] LÁSZLÓ J.: A narratív pszichológiai tartalomelemzés. Magyar Tudomány, 11 (2005), 13661375. 
Marianna SCHILD, Lívia SZIJÁRTÓ: Emotional and Cognitive Influence in Extraordinary Situations...

[30] ABRAMENKA, V.: Content analysis of British Petroleum and Tokyo Electric Power Company's crisis communication messages. Comparative analysis of crisis communication strategies. Allendale: Grand Valley State University, 2013.

[31] ALHARBI, A.: Content analysis of crisis communicative strategies: Tunisian protest vs. anti-Mubarak protest. International Journal of Human Sciences, 9 I 2 (2012), 571-586.

[32] HART, R. P., JARVIS, S. E., LIM, E. T.: The American people in crisis: A content analysis. Political Psychology, 233 (2002), 417-437. DOI: https:// doi.org/10.1111/0162-895X.00292 